\title{
Perceptions of Corporate Social Responsibility among Indonesian College Students
}

\author{
DENNI ARLI \\ Department of Marketing, Griffith Business School, Griffith University, Australia \\ TANIA BUCIC and JENNIFER HARRIS \\ School of Marketing, Australian School of Business, University of New South Wales, \\ Australia \\ HARI LASMONO \\ Faculty of Psychology, University of Surabaya, Indonesia
}

Short title: Perception of Corporate Social Responsibility

Address correspondence to Denni Arli, Department of Marketing, Griffith Business School, Griffith University, Australia. Email: d.arli@griffith.edu.au 


\begin{abstract}
Ethical consumption studies in developed countries suggest consumers are becoming more ethically minded, as manifested in the shift towards purchasing ethical products. However, little is known about ethical consumption in developing countries, which is problematic because these countries host the greatest share of the world's youth population and offer the most significant growth prospects for international companies. In this study, we examine the perceptions and motivations of Indonesian college student consumers towards CSR. We target this consumer market as they have comparatively higher spending power than the average Indonesian consumer and are thus likely to be in the position to be able to make active choices regarding CSR support. Using a two-sample approach we find that despite the country-based differenced, Indonesian college students express express perceptions of CSR similar to those of consumers in developed countries. Furthermore, female consumers have stronger intentions to support ethical products than their male counterparts, though these motives do not reliably translate into action.
\end{abstract}

KEYWORDS Corporate social responsibility, ethical Consumption, gender, developing country, Indonesia. 


\section{INTRODUCTION}

Corporate social responsibility (CSR) can make a positive difference to businesses and communities in a variety of ways (Kotler \& Lee, 2005). The recognition of and attention to local issues engenders greater social consciousness among consumers and has altered the way corporations create value. In addition to offering products for sale, firms must demonstrate their commitment to, awareness of, and responsibility toward surrounding communities (Auger et al., 2010; Caminiti, 1992; Gugler \& Shi, 2008). For example, Nestle Indonesia's CSR approach concentrates on preventive health care for children from underprivileged families, including improving access to nutritious products (i.e., milk, vitamins and food supplements) and increasing health knowledge in local communities (Rachmat, 2007). With a localised approach, businesses can earn the trust of local consumers, as well as differentiate themselves from competitors. From a business perspective, companies logically seek to understand how they can leverage their CSR initiatives to achieve market differentiation for their products (Auger et al., 2003; Honkanen, Verplanken \& Olsen, 2006; Lee \& Shin, 2010; Maignan, 2001; Strong, 1996).

Recent consumer studies confirm increased ethical consumption (Elliot and Freeman, 2001; Freestone and McGoldrick, 2008) such that in the US alone, consumers spend approximately $\$ 57$ billion on ethical products and products marketed with corporate social responsibility (CSR) (Packaged Facts, 2011). However, there have been limited studies demonstrating consumer spend or other form of return on CSR investment in developing countries. Thus, despite the progress that has been made regarding ethical consumption, much uncertainty remains surrounding the impact of CSR in terms of the perception and impact of CSR initiatives across national cultures (e.g., Auger et al., 2003; Bucic, Harris \& Arli, 2012). In a global business landscape however, understanding how company actions impact target consumer sentiment is critical for strategic value capture. 
A four-component rationale justifying why CSR in a developing country is distinct to a developed country is provided by Visser (2007, p. 474):

(1) developing countries represent the most rapidly expanding economies, and hence the most lucrative growth markets for business; (2) developing countries are where the social and environmental crises are usually most acutely felt in the world; (3) developing countries are where globalization, economic growth, investment, and business activity are likely to have the most dramatic social and environmental impacts (both positive and negative); (4) developing countries present a distinctive set of CSR agenda challenges which are collectively quite different to those faced in the developed world.

Further insights generated from a limited number of existing developing countryfocussed studies suggest that CSR is perceived in a different manner compared to consumers from developed countries (e.g., Arli \& Lasmono, 2010), which may be tied to the relative salience of localised issues (Bucic, Harris \& Arli, 2012). However, we remain uncertain of how exactly perceptions of CSR differ across different target markets (e.g., Jamali, 2007). This key dissimilarity among consumers is challenging for the 20,000 global companies who have already established operations in developing countries (Erying, Johnson \& Nair, 2010) because it restricts their communication relevance and likely limits their ability to capitalise on the economic potential of the new markets. Thus, for these and similar companies who anticipate finding 70 percent of their future sales in developing country markets (Erying, Johnson \& Nair, 2010) there is an urgent need to better understand CSR from the perspective of the developing country consumer.

Based on Bucic, Harris \& Arli’s (2012) study suggesting that Millennials represent the greatest market share both currently and in the future, and that this market is relatively well educated, feel empowered to make a difference in the world, exercise empowerment through their purchase choices and where possible, tend to give greater preference to products 
supporting salient local or health related causes, we adopt this market focus and project it to a developing country. In developing countries, where there are typically vast divisions in wealth and education among the population, the greatest proportion of well educated and implicitly, empowered consumers can be found in local colleges (World Bank, 2000). Hence, in this study, we focus on Indonesia as an appropriate example of a developing country where almost half of Indonesian population are under 25 years-old (Population Reference Bureau, 2010); and we examine the perceptions and motivations of Indonesian college student consumers towards CSR. We target this consumer market as they have comparatively higher spending power than the average Indonesian consumer and are thus likely to be in the position to be able to make choices regarding CSR support.

\section{LITERATURE REVIEW}

\section{Corporate social responsibility}

CSR refers to various ethical and socially responsible activities by a company (Carroll 1991). A detailed description frequently involves Carroll's (1979) four tenets including economic, legal, ethical, philanthropic responsibilities. That is, the foremost responsibility of business is economic, that is, to make a profit and expand; second, a business must obey the law and operate within the legal framework of society; third, businesses must respect the rights of others and meet society's expectations about what is right, just and fair; and fourth, a business should contribute to and support a broader community and improve the quality of society (Bhattacharya \& Sen, 2004; Carroll, 1991; Matten \& Moon, 2004; Sen, Bhattacharya \& Korschun, 2006; Snider, Hill \& Martin, 2003). More loosely, CSR has also been defined as a "commitment to improve community well-being through discretionary business practices and contributions of corporate resources” (Kotler \& Lee, 2005, p. 3). The connection to 
society's needs and its clear potential for positive impact has led to CSR being hailed as one of marketing’s most significant contributions to society (Varadarajan \& Menon, 1988),

However, CSR does not necessarily or directly lead to improved financial performance (McWilliams \& Siegel, 2000; Supriti \& Damodar, 2010), though some shortterm gains have been demonstrated (Mill, 2006; Tsoi, 2010). Instead, the real value of CSR is its role as "financial insurance," to help the company recover from possible negative events by strengthening its reputation, maintaining sales and accruing customer goodwill (Peloza, 2006). The capability of businesses to leverage CSR contributes to its market value, as evidenced by the choice of all Fortune 500 companies to integrate ethical approaches actively into their business practices (Hall, 2009). Thus CSR is continuing to gain momentum in the marketplace (Elliot \& Freeman, 2001; Oldenburg, 2001) and becoming a foremost concern for business (Cramer, Jonker \& Heijden., 2004).

\section{Ethical consumption}

When they respond to and even demand CSR, people are ethical consumers (Auger et al., 2010; Belk, Devinney \& Eckhardt, 2005; Newholm \& Shaw, 2007). These consumers make conscious and deliberate choices (Al-Khatib, Vitell \& Rawwas, 1996; Crane, 2001; Harrison, 2003; Vitell, Lumpkin \& Rawwas, 1991), such as purchasing products that inflict minimal harm on the environment or society (Harper \& Makatouni, 2002). A longitudinal study, conducted between 1991-2001, indicates that 66 percent of consumers actively consider a company's ethical stance when purchasing brands, 55 percent refrain from purchases if they disagree with the firm's ethical stance and as many as 80 percent of consumers believe that companies should place as much importance on social responsibility as on profitability (Ethical Consumer Research Association, 2002). However, several researchers offer contrary evidence that suggests people are not strongly committed to buying 
ethical products (Chatzidakis et al., 2004) and instead are more concerned with price or taste (Doane \& Abasta-Vilaplana, 2005; Bucic, Harris \& Arli, 2012). A discrepancy between intention and actual behaviour is stark; in a survey of UK consumers, 84 percent indicated positive intentions to support ethical initiatives, but only 5 percent regularly purchased ethical products (Cooperative Bank, 2000). Similarly, in the United States, only about 9 percent of consumers regularly purchase ethical products (Green Gauge Report, 2002).

The majority of consumers appear unaware of what CSR actually means, and furthermore, consumers who define quality of life in economic terms are unlikely to practice socially responsible consumption behaviour (Mohr et al., 2001). This situation may be explained by the Stages of Change (SOC) model (Proschaska \& DiClimente, 1983) which suggests that behavioural change occurs in series of five incremental steps: Precontemplation, Contemplation, Preparation, Action and Maintenance (see Figure 1). In an ethical behaviour context, Freestone \& McGoldrick (2008) suggest that the Decision Balance Scale (DBS) is an essential framework that corroborates a person's progression through the steps of the SOC model via its usefulness in assessing cognitive and motivational aspects of decision making. This is possible because the trade-off between anticipated benefits and cost associated with a course of action (Carey et at., 1999) is central to the DBS theory. For example, a consumer will assign differential weights to various product attributes, depending on his or her SOC and DBS, and these weights create a choice between positive and negative consequences for themselves and others (Janis and Mann, 1977).

\section{INSERT FIGURE 1}

\section{Ethical consumers in a developing country}

Implementing CSR campaigns effectively in different communities requires a thorough understanding of each set of consumers (Frynas, 2006; Singhapakdi et al. 1997, Vitell \& Rao, 1997). An example of this would be implementation at a local level to gain 
consumer trust and demonstrate understanding of and commitment to issues specific to communities. However, when companies extend their reach to developing markets, they find a shortage of relevant research on ethical consumers. As Table 1 indicates, most CSR and ethical product studies refer to developed countries. The few studies that have heeded calls for cross-cultural studies and focused on consumer responses to CSR initiatives in developing or transitional countries (see Table 2)—such as China (Ramasamy \& Yeung, 2009; Siu, 2001; Xu \& Yang, 2010); India and Turkey (Auger et al., 2010); or the Gulf region (i.e., Saudi Arabia, Oman \& Kuwait) (Al-Khatib et al., 2003) — offer limited practical and theoretical insights regarding consumer motivations. No empirical studies have investigated ethical consumption in large developing countries either.

\section{INSERT TABLE 1 and 2}

Even if consumers are interested in supporting ethical products and have broadly similar interests and commitments to CSR, their attitudes vary depending on both cultural factors and gender (Auger et al., 2008; Belk, Devinney \& Eckhardt, 2005; Singhapakdi, Vitell \& Rao, 1997; Srnka, 2004; Vitell, 2003). For example, in developed countries competing ethical products are available, and consumers generally have more resources that enable them to pay premium prices to support their social consciousness (e.g., Auger et al., 2010; De Pelsmacker, Driesen \& Rayp, 2005; Yates, 2011). In contrast, consumers in developing countries tend to rely heavily on brand image as an indicator of quality, which may reduce the importance of social attributes (Auger et al., 2010). Consumers in developing economies also rarely can afford to act on their social consciousness, especially when ethically labelled products are more expensive (Auger et al., 2010; Siu, 2001). Thus, we ask what might motivate consumers in developing countries to undertake ethical purchasing? 
Beyond cultural factors, demographic characteristics such as gender may determine ethical decision making too (Rawwas, 1996; Ross, Patterson \& Stutts, 1992). For example, female consumers appear more favourably predisposed toward ethically oriented appeals (Meyers-Levy, 1989). Gender also influences donation behaviours and pro-social activities; women have a greater tendency to trust marketing claims, whereas men often believe an organisation is taking advantage of consumers by exploiting causes (Ross, Patterson \& Stutts 1992).

Although various studies examine gender differences in ethical leadership (Eagly and Johnson, 1990), ethical perceptions and behaviour (Franke, Crown, Spake, 1997; Thoma, 1986), no analyses address the role of gender for CSR and ethical consumption in developing countries. Yet gender may take on particular importance for decision-making processes in developing countries, because women tend to be the primary decision makers in household purchase situations (Raajpoot, Sharma \& Chebat, 2007; Ramaun, 2011). In turn, we investigate how gender affects the evaluation of CSR initiatives in developing countries.

\section{Conceptual Model}

The conceptual model for this study is based on an integration and replication of two prior studies: Maignan’s (2001) investigation of gender-based consumer perceptions of CSR; and Freestone and McGoldrick’s (2008) exploration of product attributes considered in purchase decisions and consumer motivations for ethical behaviour. As part of the latter, we also examine the Decision Balance Scale (DBS) and Stages of Change (SOC) model (Freestone \& McGoldrick, 2008). We are thus able to explore consumer perceptions toward CSR in a developing country setting. 


\section{Developing country consumers}

In terms of investigating ethical consumers, Indonesia presents two challenges. First, only one-quarter of large Indonesian companies market themselves as having ethical policies and practices, compared with 75 percent of them in India, 42 percent in Thailand, 32 percent in Malaysia and 30 percent in the Philippines (Chapple \& Moon, 2005). Even when corporations in Indonesia profess to recognize the value of ethical responsibilities, they produce products using methods that can cause immense destruction, both locally and globally, and no government intervention limits their actions (Hill, 1996; Kemp, 2001). Both the government and corporations in Indonesia prompt negative perceptions among Indonesian consumers. Second, Indonesian people earn generally relatively low incomes; in 2008, Indonesia’s annual gross national income purchasing power parity per capita was US\$3,830, and 47.1 percent of people's earnings went to food and related purchases (Population Reference Bureau, 2010). Thus, for Indonesian consumers, spending more to support a CSR campaign is inherently a complex choice and awareness of CSR is likely limited.

$\mathbf{H}_{1}$ : $\quad$ Consumers in Indonesia will NOT be able to distinguish the different types of CSR.

Nonetheless, extending Freestone and McGoldrick’s (2008) study, we examine whether a shift in the DBS occurs as a consumer progresses through awareness, concern and action stages as per the SOC model. That is, an individual will consider a trade-off between anticipated gains (benefits) and losses (costs) associated with a course of action. We seek to determine whether the DBS and SOC models hold in the context of a developing country. That is, whether or not consumers in a developing country can be broadly categorised using their positive and the negative values and a series of motivational statements from the DBS and SOC models.

$\mathrm{H}_{2}$ : $\quad$ The DBS and SOC models, used to describe ethical behaviour, hold in the context of Indonesia. 


\section{The impact of gender on ethical consumption in a developing country}

In studies that examine consumer perceptions, women tend to behave more prosocially than men and are more likely to respond positively to CSR campaigns (Becker, 1986; Eagly and Crowley, 1986; Maignan, 2001; Moosmayer \& Fuljahn, 2010; Skoe et al., 2002). However, these studies all feature samples from developed countries (Sikula \& Costa, 1994). In contrast, cultural studies suggest that in developing countries, the role of women differs from that in developed nations, women rarely possess equal rights with men, and likewise, their values may differ from those of women in developed countries (Hosftede \& Bond, 1984). For example, women in Indonesia remain acutely underrepresented in higher education, political decision making and higher civil service ranks. Nevertheless, they are the primary decision makers in most household purchase decisions (Robinson \& Bessel, 2002). They also are more likely to be unemployed than men: 41 percent of women, versus 73 percent of men, are employed or actively seeking employment. Moreover, women are also underrepresented in the formal wage sector and often earn only about 81 percent of what men earn in Indonesia (World Bank, 2006). However, despite compelling arguments regarding the differences between men and women, some studies offer contrary findings which suggest that men and women are ethically equivalent (i.e., McDonald \& Pak, 1996; Sikula \& Costa, 1994; Sim, 1999). If genders are ethically equivalent, then each would place the same level of importance on the various CSR responsibilities, and consider CSR product attributes similarly. In this paper, we hypothesise that gender will not affect consumer responses toward CSR initiatives in developing countries:

$\boldsymbol{H}_{3}$ : $\quad$ Men and women in Indonesia are NOT ethically equivalent, that is, they DO NOT place the same level of importance on CSR responsibilities.

$\boldsymbol{H}_{4}: \quad$ In purchase decision contexts, there are NO significant differences in the social attributes considered by men and women. 
Freestone and McGoldrick (2008) argue that progression through the stages of change depends on the salience a person allocates to positive and negative value statements and personal and social value statements, as part of the DBS. For instance, social motivators are stronger levers of ethical behaviour than are personal ones. As awareness of and concern about issues increases, a person progresses through the stages toward eventual action in the form of the desired behaviour - such as ethical purchasing. At this point, agreement with positive motivations (gains) increases; agreement with negative motivations (losses) decreases. Thus, a person who is in the earlier stages of ethical awareness will be less likely to agree with the motivational statements that suggest an ethical behaviour is beneficial to both themselves and the wider society (Freestone \& McGoldrick, 2008). Hence we assume similar progress for men and women in developing countries, therefore we hypothesise:

$\boldsymbol{H}_{5 a}: \quad$ The social positive and personal positive scales for women in developing countries are higher in later stages of awareness, concern and action, compared with early stages.

$\boldsymbol{H}_{5 b}$ : The social negative and personal negative scales for women in developing countries are lower in later stages of awareness, concern and action, compared with early stages.

$H_{6 a}: \quad T h e$ social positive and personal positive scales for men in developing countries are higher in the later stages of awareness, concern and action, compared with early stages

$\boldsymbol{H}_{6 b}$ : The social negative and personal negative scales for men in developing countries are lower in the later stages of awareness, concern and action, compared with early stages.

\section{METHODOLOGY}

This paper is comprised of two studies, both set in Indonesia. Study 1 aims to investigate consumer perceptions toward CSR; Study 2 investigates attributes consumers consider when purchasing CSR products and their motives. The cumulative outcome is a more complete understanding of consumers’ perceptions and motivations toward companies’ 
CSR and ethical purchasing, as well as the role of gender in product consumption in Indonesia.

\section{Setting}

Indonesia is a large developing country, situated in South Asia, the latter which accounts for more than a quarter of the world's youth and is considered as the most youthful sub-region in the world (Population Reference Bureau, 2010). Indonesia hosts the world's fourth largest population at approximately 235 million inhabitants, where half are under 25 years old (Population Reference Bureau, 2010; DAFF, 2010).

Localised studies suggest that these young Indonesian consumers demonstrate divergence from traditional spending patterns because they are willing to spend more on nonessential goods and services. Furthermore, more socially and environmentally conscious youth in Indonesia are confidently making consumption choices that are consistent with their beliefs, and they are eager to jump on the purchasing bandwagon once a trend arises (HKTDC, 2011; Euromonitor, 2007). For example, 76 percent of all (metropolitan) Indonesians 14-24 years old own a mobile phone (Guharoy, 2010), 84 percent own a PC, and 67 percent access news online (Nielsenwire, 2010).

Indonesia is considered as a major market for international companies as they seek to diversify their business interests by entering developing countries to grow their market share. However, an incomplete understanding of the complexities of the developing country consumer make localised operations challenging. In Indonesia for example, there are many differences between regions, subgroups, rural and urban consumers. Furthermore, there are diverse religions governing lifestyle and consumption choices, and presence of at least 700 spoken languages which magnify the black box of the developing country consumer. The 
resulting effect is of difficulty in value capture and communication among marketers for consumers in developing countries.

\section{Study 1}

Maignan (2001) investigates consumers' readiness to support socially responsible organizations in developed countries (i.e., France, Germany and the United States), including their evaluations of the economic, legal, ethical and philanthropic responsibilities of the firm. Study 1 replicates Maignan's (2001) work by employing a convenience sample of undergraduate students from a university in Indonesia. The 443 usable surveys include 81 percent female and 19 percent male students, ranging in age from 16 to 23 years (62\% 16-19 years, 38\% 20 years or older).

The survey instrument used scales originally developed by Maignan (2001) that have been examined in other contexts (e.g., China; Ramasamy \& Yeung, 2009). We measured consumers' CSR evaluations with 16 attributes, across the four groups of economic, legal, ethical and philanthropic responsibility (Carroll, 1979). The measures all used a five-point scale (1= “strongly disagree” to $5=$ "strongly agree”). We also measured consumers” support for responsible business practices using a five-point adaptation of Maignan's (2001) scale, as previously implemented by $\mathrm{Lu}$ and Liu (2000). The questionnaire was first translated into Indonesian and then back-translated into English to ensure equivalence.

\section{Study 2}

Study 2 yielded 409 completed questionnaires, of which 371 were usable. The sample was gathered from students at three large private universities in Surabaya, Indonesia. Surabaya is the second largest city in Indonesia with around 3 million inhabitants in 2011. The voluntary study was promoted in undergraduate classes by lecturers, with hard copies of 
the questionnaire distributed to students. The respondents ranged in age from 16 to 25 years (71\% 16-19 years, 21\% 20-21 years, 8\% 22-25 years), and they were nearly evenly split in terms of gender, with 48 percent men and 52 percent women.

Key aspects of this study were based on Freestone \& McGoldrick’s (2008) work, which has demonstrated that consumers' motivational attitudes are a function of their stage of ethical awareness, concern and action, as well as that social motivators are stronger levers for ethical behaviour than personal ones. Their study was the first to examine and find support for ethical decision making using the DBS and SOC models (Prochaska \& DiClemente, 1984).

The questionnaire consisted of four sections. Section 1 gathered consumption behaviour by asking about the frequencies of purchase and the type of cause associated with the products purchased. Section 2 contained awareness and motivation items, in terms of products associated with four causes (i.e., clean water in the Third World, health, environmental damage, and localised problems). The constructs came from existing scales. Motivations to purchase according to CSR were measured using the DBS (Freestone \& McGoldrick, 2004). The level of agreement or disagreement with 19 statements was measured on a seven-point scale ( $1=$ "strongly disagree" to $7=$ "strongly agree"). Furthermore, we used Freestone and McGoldrick’s (2008) six-point, single-item SOC measure to examine level of awareness and concern for each of the fours causes (i.e., health, environmental damage, problems in third world and local problem). Respondents were asked to indicate their level of awareness, concern and action (ACA) (1="not noticed this issue"; 2="aware but no greatly concern"; 3="aware and concerned but not taken action"; 4=”concerned and taken minor action”; 5= “concerned and taken major action”). Section 3 linked companies' brands to particular causes $(1=$ "strongly disagree" to 7 = "strongly 
agree”) by asking about consumers' likelihood to purchase that brand (1 = "very unlikely" to 7 = “very likely”). Section 4 collected demographic information.

To gain insights from these data and test the hypotheses, we applied a range of techniques, including t-tests, chi-square tests, one-way analyses of variance (ANOVA) and repeated measures ANOVA. All analyses used SPSS version 18.

\section{ANALYSIS AND FINDINGS}

\section{Consumers’ perceptions of CSR in Indonesia}

To measure consumers' perceptions of CSR in Indonesia it was first necessary to determine their awareness of the CSR concept. We thus conducted a factor analysis on Carroll's (1979) four tenets of CSR, and the results reveal a four-factor structure after the removal of seven items due to their low communality $(<0.5)$ or low or double loading (see Table 3). Each factor represents a specified type of corporate social responsibility. The loadings exceed 0.5 (Hair et al., 1998) and the variances explained are greater than 60 percent. Communality and eigenvalues also meet the recommended guidelines (Hair et al. 1998). This suggests that Indonesian consumers do possess awareness of the CSR concept and can distinguish among the tenets of CSR (i.e., economic, legal, ethical and philanthropic). Hence $\mathrm{H}_{1}$ is rejected.

\section{INSERT TABLE 3}

\section{Ethical consumers}

In line with Freestone \& McGoldrick’s (2008) findings, items from the DBS follow a pros versus cons dichotomy. Using Varimax rotation, after deleting low loading items, we achieved a two-component, 16-item solution, which indicated that consumers in developing countries recognize both positive and negative motivations for ethical decisions (see Table 4). The positive and negative components explain 43.4 percent of the variance in the reduced 16- 
item scale, and we find support for the factors' reliability, Cronbach's alpha values of 0.809 for the pros subscale and 0.803 for the cons subscale. The relative loadings of positive items are consistent with Freestone \& McGoldrick's (2008) study, though we find different loadings for the negative terms, including the three strongest loadings which reflect the potential loss of convenience or choices when taking the selected ethical issue into account when shopping. However, overall, we find support for $\mathrm{H}_{2}$.

\section{INSERT TABLE 4}

Noting the low percentage variance explained in the two-factor solution, we undertook a further factor analysis that suggested splitting the pro and con factors, revealing a four-factor solution (Table 5). Seven items were removed in this process due to low communality $(<0.5)$ or low or double loading; all remaining items loaded at least at 0.5 (Hair et al., 1998), and the variance explained increased to greater than 60 percent. Although we use fewer items than Freestone \& McGoldrick (2008), our results align. Motivations to purchase CSR products thus can be explained in terms of personal positive and negative and social positive and negative motivations (Freestone \& McGoldrick, 2008).

\section{INSERT TABLE 5}

\section{Impact of gender}

To test whether differences existed between males and females in terms of their response to CSR initiatives, we explored the importance the genders placed on the types of CSR responsibilities, i.e. economic, legal, philanthropic and ethical. From a series of repeated measures ANOVA, it emerged that there were no significant differences in the degree of importance allocated to economic or philanthropic responsibilities by men or women, whereas the ethical and legal responsibilities indicated significant differences (see Tables 6 and 7). Women ranked social responsibilities, in decreasing order of importance, by putting philanthropic and economic first (with no significant difference), then ethical and finally 
legal responsibilities. Similarly, men’s rankings indicated economic and philanthropic first, followed by ethical and then legal responsibilities. These rankings suggest no gender differences, though the magnitude of importance of the economic factor differs (Table 8). Hence $\mathrm{H}_{3}$ is not supported, that is, males and females are ethically equivalent. Both men and women consider economic responsibility important, but men rate it significantly more important. Legal responsibilities are the least important social responsibility for consumers in Indonesia.

\section{INSERT TABLES 6-8}

Further explorations indicate no differences between males and females in their considerations of more traditional purchase factors, such as quality, price, brand, ingredients, packaging or convenience. However, differences emerge related to social attributes, such as the items "when the product supports a charity" and "what charity it supports" (Table 9). In line with previous studies in developed countries (e.g., Ross, Patterson \& Stutts., 1992), women in Indonesia are more likely to consider whether a product supports a charity and what charity it supports. Thus, women have a more favourable attitude towards CSR, and we must reject $\mathrm{H}_{4}$.

\section{INSERT TABLE 9}

In general, women and men do not differ in their awareness of or concern for a range of issues, with the exception of climate change, for which women indicate greater concerns. Samy (2011) suggests an explanation: Climate changes may worsen gender inequality in developing countries, because many labour-intensive activities, such as gathering water for subsistence farming, are primarily women's responsibility and are likely to become increasingly difficult with climate changes (see Table 10).

INSERT TABLE 10 


\section{Ethical motivation and gender}

To explore the impact of the stage of awareness and concern (SOC) on motivation, we conducted a series of ANOVAs, followed by post-hoc tests. The separate analyses for men and women helped uncover the gender differences. Prior to the tests, we also explored the hypotheses using visual analysis (Figures 2 and 3). The figures contain only three stages of awareness and concern, rather than five stages, because of the very small number of female respondents in the "aware but not greatly concerned" and "concerned and taken major action" categories ( $n=3$ and $n=2$, respectively). More men appeared in these two categories, but the numbers still were not substantial. For consistency, we combine these categories with others for both genders.

\section{INSERT FIGURES 2 AND 3}

As visual assessment lacks rigor, the statistical tests provide support for the results. For women, social positive and personal positive motivations increase with greater awareness and concern $\left(p<0.05\right.$; Table 11), in support of $\mathrm{H}_{5 \mathrm{a}}$. However, though Figure 2 indicates that the mean of women's social negative and personal negative motivations generally increase with awareness and concern, the differences are not statistically significant $(p<0.05$; Table 11), so we cannot confirm $\mathrm{H}_{5 b}$.

\section{INSERT TABLE 11}

The pattern of social and personal motivations across stages of awareness and concern for men is quite different. Figure 3 indicates that changes in men's social and personal motivations across stages are not unidirectional. This is not to say that males, like females, who are in the 'aware but not greatly concerned' category do not have a lower average social positive and personal positive motivation. The results in Table 12 indicate that these values differ significantly. However unlike women, men's social positive and personal positive motivations are not significantly different across all Awareness, Concern, and Action (ACA) 
stages. Similarly, there are no significant differences across ACA stages for men's social negative and personal negative motivations. Consequently, we must reject both $\mathrm{H}_{6 a}$ and $\mathrm{H}_{6 \mathrm{~b}}$. In general, for both genders, social positive and personal positive motivations are the strongest drivers. We summarise our hypotheses results in Table 13.

INSERT TABLE 12 and 13

\section{MANAGERIAL IMPLICATIONS}

The findings from this study provide a more complete description of the Indonesiancollege-student-as-consumer perceptions and motivations towards CSR In Indonesia, this age group represents a powerful market for many products and services. In addition, this age group contribute to a significant number of families/ married couples in the future. A study shows that around 80.5 percent of people between 25-29 years are married and 96 percent of people in Indonesia still disagree that marriage is outdated (Global Family Trends, 2011).

The study found that men and women have similar perceptions of CSR, in line with studies of ethical consumers in developed countries that suggest ethical buying behaviour is not influenced by gender (e.g., Sikula \& Costa, 1994; Tsalikis \& Ortiz-Buofina, 1990). However economic responsibilities are of greater importance for men. In a male-dominated society, men tend to be the primary income earners in the family, and women may not be expected to generate income. Women thus work fewer hours in paid employment and may pay less attention to economic responsibility. Yet women are the primary consumption decision makers for households, accounting for 74 percent of Indonesian shoppers (Ramaun, 2011). They also offer a higher score for support of ethical consumption than men. However, women's concern for and awareness of ethical consumption does not appear to readily translate to purchases, particularly when they lack surplus monies to spend on more expensive ethical products. 
Instead, quality, price and brand are the primary drivers of purchase decisions about everyday products among Indonesian consumers. This finding confirms that with their limited spending power, Indonesian consumers remain quality and price conscious. However, significant differences emerge between female and male consumers in terms of their perceptions of the social attributes causes being supported. Although the mean values are low, women continue to express a more positive attitude toward CSR than men, consistent with our findings from Study 2, in which women indicate higher levels of awareness and concern regarding various social issues (i.e., health, climate change and environmental damage) and greater likelihood to take action compared with men.

Furthermore, our findings of partial support for the DBS scale implies that consumers in a developing country, who are in a pre-contemplative, unconcerned stage, do not perceive greater benefits than costs of a possible change in behaviour. Nevertheless, in the ACA stages, growth was more apparent for women, who indicate both social positive and personal positive motivations. Social negative and personal negative motivations were consistent across genders.

These findings offer a more detailed understanding of the shift in positive and negative motivations as a consumer progresses from pre-contemplation toward action. However, the transformations do not necessarily imply a systematic approach to ethical behavioural changes by consumers in developing countries such as Indonesia. This finding might reflect the distinctive nature of consumers in a developing country, who are confronted with daily economic, political and social struggles. Notwithstanding, our research suggests some opportunities for marketers to concentrate on female consumers, with their greater propensity to support CSR activities.

Businesses operating in developing countries should realise that CSR efforts targeting female consumers possibly improve the likelihood of their success. In Indonesia, women 
make the vast majority of purchasing decisions, and when they may choose among similar products, they may select a product that supports a certain cause or take action toward social issues. Consumers want to believe they are making a difference; without access to the workforce, Indonesian women may find purchasing ethical products as a way to become empowered to make a difference in their communities. Thus, there is an opportunity for companies to provide more specific ethical products that appeal to female consumers.

\section{Limitations and further research}

Some limitations in this study also offer opportunities for future research. First, we used a cross-sectional research design, limited to one developing country, at one point in time, and with one demographic group, college students. Though there is no typical college student across a country as diverse as Indonesia, the vast numbers of college students represent a significant market for consumer products can enable some general insights to be drawn.

Notwithstanding, the findings may not be directly relevant to other age groups, and might shift over time. Furthermore, the vast majority of respondents in Study 1 were women. We executed a series of repeated measures, using separate female and male groups, to avoid any obvious bias, but the gender skew might have an impact. Second, consistent with other studies, we considered only consumers' perceptions and intentions. There may be differences between intentions and consumers' actual behaviours in terms of supporting CSR (Maignan, 2001). Third, we do not differentiate various types of companies (e.g., locally owned versus foreign investments). Consumers might have different expectations of and responses toward various companies. Fourth, the role of brand image is a powerful lever in purchase decisions particularly among those in developing countries. This has not been explored in this paper however, would be valuable for future research. Finally, several studies suggest that ethical 
consumers have relatively higher levels of education (Carrigan \& Attala, 2001; Maignan \& Ferrell, 2001; De Pelsmacker, Driesen \& Rayp, 2005). Therefore, future research should include respondents who represent various age groups, income strata and education levels, which may yield more fine-grained insights. 


\section{REFERENCES}

Al-Khatib, J.A., Stanton, A.D., \& Rawwas, M.Y.A. (2003). Ethical segmentation of consumers in developing countries: a comparative analysis. International Marketing Review, 22, 225-246.

Al-Khatib, J.A., Vitell, S., \& Rawwas, M.Y.A. (1996). Consumer ethics: a cross-cultural investigation. European Journal of Marketing, 31, 750-767.

Arli, D., \& Lasmono, H. (2010). Consumers' perception of corporate social responsibility in a developing country. International Journal of Consumer Studies, 34 (1), 46-51.

Auger, P., Burke, P., Devinney, T.M., \& Louviere, J.J. (2003). What will consumers pay for social product features?, Journal of Business Ethics, 42, 281-304.

Auger, P,, Devinney, T.M., Louviere, J.J., \& Burke, P.F. (2008). Do social product features have value to consumers?. International Journal of Research in Marketing, 25, 183-191.

Auger, P., Devinney, T.M., Louviere, J.J. \& Burke, P.F. (2010). The importance of social product attributes in consumer purchasing decisions: A multi-country comparative study', International Business Review, 19, 140-159.

Becker, B.J. (1986). Influence again: An examination of reviews and studies of gender differences in social influence. In J. S. Hyde \& M. C. Linn (Eds.), The psychology of gender: Advances through meta-analysis (pp. 178-209). Baltimore: Johns Hopkins University Press.

Becker-Olsen, K.L., Cudmore, A, \& Hill, R.P. (2006). The impact of perceived corporate social responsibility on consumer behaviour. Journal of Business Research, 59, 46-53.

Beckmann, S. (2007). Consumers and corporate social responsibility: matching the unmatchable. Australian Marketing Journal 15 (1), 27-35.

Belk, R.W., Devinney, T.M. \& Eckhardt, G. (2005). Consumer ethics across cultures. Consumption, Markets and Culture, 8 (3), 275-289.

Berry, H., \& McEachern, M.G. (2005). Informing ethical consumers, in R. Harrison, T. Newholm and D. Shaw (eds.). The Ethical Consumer, London, Sage, pp. 69-88.

Betz, M., O’Connel, L., \& Shepard, J.M. (1989) Gender differences in proclivity for unethical behaviour. Journal of Business Ethics, 8, 321-4.

Bhattacharya, C.B., \& Sen, S. (2004). Doing better at doing good: when, why, and how consumers respond to corporate social initiatives. California Management Review, 47, 9-24.

Bray, J., Johns, N., \& Kilburn, D. (2011). An exploratory study into the factors impending ethical consumption. Journal of Business Ethics, 98, 597-618.

Brown, T.J., \& Dacin, P.A. (1997). The company and the product: corporate associations and consumer product responses. Journal of Marketing, 61, 68-84. 
Brunk, K.H. (2010). Reputation building: beyond our control? inferences in consumers' ethical perception formation. Journal of Consumer Behaviour, 9, 275-292.

Bucic, T., Harris, J. \& Arli, D. (2012). Ethical consumers among the millenials: a crossnational study. Journal of Business Ethics, 110, 113-131.

Caminiti, S. (1992). The payoff from a good reputation. Fortune, 125, 74-77.

Carey, K.B., Purnine, D.M., Maisto, S.A., Carey, M.P., \& Barnes, K.L. (1999). Addictions services: decisional balance regarding substance use among persons with Schizophrenia, Community Mental Health Journal, 35, 289-299.

Carrigan, M., \& Attalla, A. (2001). The myth of the ethical consumer-do ethics matter in purchase behavior?. Journal of Consumer Marketing, 18, 560-577.

Carroll, A.B. (1979). A three-dimensional conceptual model of corporate social performance. Academy of Management Review, 4, 497-505.

Carroll, A.B. (1991). The Pyramid of corporate social responsibility: toward the moral management of organizational stakeholders. Business Horizons, 34, 39-48

Chapple, W., \& Moon, J. (2005). Corporate social responsibility in Asia: aseven-country study of CSR website reporting. Business and Society, 44, 415-41.

Chatzidakis, A., Sally, H., Darryn, M., \& Andrew, S. (2004). Virtue in consumption?. Journal of Marketing Management, 20 (5-6), 526-43.

Cooperative Bank. (2000). Who are the ethical consumers? Retrieved from http://www.google.com.au/search?sourceid=chrome\&ie=UTF-

8\&q=Cooperative+Bank\%2C+2000.+Who+are+the+Ethical+Consumers\%3F.

Coulson, N.S. (2000). An application of the stages of change model to consumer use of good labels. British Food Journal, 102, 661-668.

Cramer, J., Jonker, J. \& Heijden, A. (2004). Making sense of corporate social responsibility. Journal of Business Ethics, 55, 215-222.

Crane, A. (2001). Unpacking the Ethical Product. Journal of Business Ethics, 30, 361-373.

Creyer, E.H., \& Ross, Jr. W.T. (1996). The impact of corporate behaviour on purchase intention: do consumers really care about business ethics?. Journal of Consumer Marketing, $14,421-432$.

DAFF, Australia Department of Agriculture, Fisheries and Forestry (2010). Indonesian consumers. Retrieved from

http://www.daff.gov.au/_data/assets/pdf_file/0009/183564/indo_chapter2.pdf.

De Pelsmacker, P,, Driesen, L., \& Rayp, G. (2005). Do consumers care about ethics? Willingness to pay for fair-trade coffee. Journal of Consumer Affairs, 39, 363-385. 
Doane, D.,\& Abasta-Vilaplana, N. (2005). The myth of CSR. Stanford Social Innovation 3, 22-29.

Eagly, A.H., \& Johnson, B.T. (1990). Gender and leadership style: a meta-analysis. Psychological Bulletin, 108, 233-256.

Eagly, A.H., \& Crowley, M. (1986). Gender and helping behavior: a meta-analytic review of the social psychological literature. Psychological Bulletin, 100, 283-308

Elliot, K.A.,\& Freeman, R.B. (2001). White hats or Don Quixotes? Human rights vigilantes in the global economy. Working Paper 8102, National Bureau of Economic Research, Cambridge, MA.

Erying, M., Johnson, M.W., \& Nair, H. (2010). New business models in emerging markets. Retrieved from http://hbr.org/2011/01/new-business-models-in-emerging-markets/ar/1.

Ethical Consumer Research Association. (2002). Ethical consumer issue, 76 (April/May).

Euromonitor. (2007). Indonesian young population as key driver to consumer marketing growth. Retrieved from http://blog.euromonitor.com/2007/06/indonesian-young-populationas-key-driver-to-consumer-market-growth.html

Franke, G.R., Crown, D.F., \& Spake, D.F. (1997). Gender difference in ethical perceptions of business practices: asocial role theory perspective. Journal of Applied Psychology, 82, 920934.

Freestone, O.M, \& McGoldrick, P.J. (2008). Motivations of the ethical consumer. Journal of Business Ethics, 79, 445-467.

Frynas, J.G. (2006). Corporate social responsibility in emerging economies. Journal of Corporate Citizenship 24, winter, 16-19.

Global Family Trends. (2011). Indonesia country profile. Retrieved from http://globalfamilytrends.com/data/country-profiles/Asia/Indonesia.pdf.

Glover, S.H., Bumpus, M.A., Sharp, G.F., \& Munchus, G.A. (2002). Gender differences in ethical decision making. Women in Management Review, 17, 217-27.

Green Gauge Report. (2002). Americans perspective on environmental issues yes...but. Retrieved from http://courses.be.washington.edu.

Gugler, P., \& Shi, J.Y.J.(2008). Corporate social responsibility for developing country multinational corporations: lost war in pertaining global competitiveness?. Journal of Business Ethics, 87, 3-24.

Guharoy, D. (2010). Analysis: how powerful is the youth Indonesian consumer?. Retrieved from http://www.thejakartapost.com/news/2010/10/26/how-powerful-young-indonesianconsumer.html 
Hair, J., Anderson, R., \& Tatham, B. W.(1998). Multivariate Data Analysis, $5^{\text {th }}$ ed., (PrenticeHall, Upper Saddle River, NJ).

Hall, H. (2009). Corporate and individual giving: what to expect in coming months. Chronicle of Philanthropy, 21, 3.

Harper, G.C., \& Makatouni, A. (2002). Consumer perception of organic food productions and farm animal welfare. British Food Journal, 4, 287-299

Harrison, R. (2003). Corporate social responsibility and the consumer movement. Consumer Policy Review,13, 127-131.

Hill, H. (1996). The Indonesian economy since 1986: South East Asia's emerging giant. Cambridge University Press, Cambridge, U.K.

HKTDC (2011). The changing Indonesian consumer. Retrieved from http://www.hktdc.com/info/vp/a/elec/en/1/6/1/1X07BQL9/The-Changing-Indonesian-

Consumer.htm.

Honkanen, P., Verplanken, B., \& Olsen, S.O. (2006). Ethical values and motives driving organic food choice. Journal of Consumer Behaviour, 5, 420-430.

Hofstede, G. \& Bond, M.H. (1984). Hofstede's cultural dimensions: An independent validation using Rokeach's value survey. Journal of Cross-cultural Psychology, 15(4): 417433.

Jamali, D. (2007). The case for strategic corporate social responsibility in developing countries. Business and Society Review, 112, 1-27

Janis, I.L, \& Mann, L. (1977). Decision making: a psychological analysis of conflict, choice and Commitment (Free Press, New York).

Kemp, M. (2001). Corporate social responsibility in Indonesia: quixotic dream or confident expectation?, Technology, Business and Society Programme Paper no. 6, Geneva. United Nations Research Institute for Social Development.

Kotler, P., \& Lee, N. (2005). Corporate social responsibility. doing the most good for your company and your cause. Hoboken, NJ: Wiley.

Lee, K.H., \& Shin, D. (2010). Consumers responses to CSR activities: The linkage between increased awareness and purchase intention. Public Relations Review, 36, 193-195.

Lu, X., \& Liu, M. (2000). Adapting the Servqual Scale to China Hospitals Services. ICMIT: 204-208.

Maignan, I. (2001). Consumers' perception of corporate social responsibilities: a crosscultural comparison. Journal of Business Ethics, 30, 57-72.

Maignan, I., \& Ferrell, O.C. (2000). Measuring corporate citizenship in two countries: the case of the United States and France. Journal of Business Ethics, 23, 283-297. 
Matten, D., \& Moon, J. (2004). 'Implicit' and 'explicit' CSR: a conceptual framework for understanding CSR in Europe. ICCSR Research Paper Series, 29.

Meyers-Levy, J. (1989). Gender differences in information processing: a selectivity interpretation in cognitive and affective responses to advertising, eds. P. Cafferata and Alice Tybout, MA: Lexington Books, 219-260.

McDonalds, G., \& Pak, P.C. (1996). It's all fair in love, war, and business: cognitive philosophies in ethical decision making. Journal of Business Ethics, 15, 973-96.

McGoldrick, P.J., \& Collinsn, N. (2007). Multichannel retailing: profiling the multichannel shopper. Review of Retail, Distribution and Consumer Research, 17, 139-158.

McWilliams, A., \& Siegel, D. (2000). Corporate social responsibility and financial performance: correlation or misspecification?. Strategic Management Journal, 21, 603-609.

Mill, G.A. (2006). The financial performance of a socially responsible investment over time and a possible link with corporate social responsibility. Journal of Business Ethics, 63, 131148.

Miller, W. R., \& Rollnick, S. (2002). Motivational interviewing: preparing people to change addictive behavior (2nd ed.). New York: Guilford Press

Moosmayer, D.C., \& Fuljahn, A. (2010). Consumer perceptions of cause related marketing campaigns. Journal of Consumer Marketing, 27, 543-549.

Mohr, L.A., Webb, D.J., \& Harris, K.E. (2001). Do consumers expect companies to be socially responsible? The impact of corporate social responsibility on buying behavior. Journal of Consumer Affairs, 35, 45-72.

Mohr LA, \& Webb DJ. (2005). The effects of corporate social responsibility and price on consumer responses. Journal of Consumer Affairs, 39 (1), 121-147.

Newholm, T., \& Shaw, D. (2007). Studying the ethical consumer: a review of research. Journal Consumer Behaviour, 6, 253-270.

Nicholls, A. (2002). Strategic options in fair trade retailing. International Journal of Retail Distribution Management, 30, 6-17.

Nielsenwire (2010). Tapping the buying power of Indonesia's young professionals. Retrieved from http://blog.nielsen.com/nielsenwire/consumer/tapping-the-buying-power-of-indonesiasyoung-professionals/.

Oldenburg, D. (2001). Selling well doing good. Washington Post (November): C12.

Packaged Facts. (2011). Market for ethical consumer products soaring: sales to reach \$57 billion by 2011. Retrieved from http://www.packagedfacts.com/about/release.asp?id=833

Peloza, J. (2006). Using corporate social responsibility as insurance for financial performance. California Management Review, 48, 52-72. 
Population Reference Bureau. (2010). Data by geography, Indonesia, summary. Retrieved from http://www.prb.org/Datafinder/Geography/Summary

Prochaska, J., \& DiClemente, V. (1984). The Transtheoretical Approach: Crossing Traditional Boundaries of Therapy (Homewood, IL: Dow Jones-Irwin).

Prochaska J.O., Velicer, W.F., Rossi, J.S., Goldstein, M.G., Marcus, B.H., Rakowski, W., Fiore, C., Harlow, L.L., Redding, C.A., Rosenbloom, D., \& Rossi, S.R. (1994). Stages of Change and Decisional Balance for 12 Problem Behaviour. Health Psychology, 13, 39-46.

Raajpoot, N.A., Sharma, A, \& Chebat JC. (2007). The role of gender and work status in shopping center patronage. Journal of Business Research, 61, 825-833.

Rachmat, A. (2007). Diary firms' CSR focus on preventive health care. Retrieved from http://www.thejakartapost.com/news/2007/11/21/diary-firms039-csr-focus-preventive-healthcare.html.

Ramasamy, B., \& Yeung, M. (2009). Chinese consumers' perception of corporate social responsibility (CSR). Journal of Business Ethics, 88, 119-132.

Ramaun, F. (2011). In a shift, one in four Indonesian household shoppers now men. Retrieved from http://blog.nielsen.com/nielsenwire/consumer/in-a-shift-one-in-fourindonesian-household-shoppers-now-men/.

Rawwas, M.Y.A. (1996). Consumer ethics: an empirical investigation of the ethical beliefs of Austrian consumers. Journal of Business Ethics, 15(9), 1009-1019.

Robinson, K., \& Bessel, S. (2002). Women in Indonesia: gender, equity and development (Indonesia assessment series)'. Institute of Southeast Asian Studies. Pasir Panjang, Singapore.

Ross, J.K., Patterson, L., Stutts, M.A. (1992). Consumer perceptions of organizations that use cause-related marketing. Journal of the Academy of Marketing Science, 20, 93-97.

Samy, K. (2011). Women and climate change: an opportunity to address gender inequality. Retrieved from http://yalejournal.org/wp-content/uploads/2011/03/116114samy.pdf.

Sen, S., \& Bhattacharya, C.B. (2001). Does doing good always lead to doing better?Consumer reactions to corporate social responsibility. Journal of Marketing Research, $38,225-243$.

Sen, S., Bhattacharya, \& C.B, Korschun, D. (2006). The role of corporate social responsibility in strengthening multiple stakeholder relationships: a field experiment'. Academy of Marketing Science Journal, 34, 158.

Sikula, A., \& Costa, A.D. (1994). Are women more ethical than men?. Journal of Business Ethics, 13, 859-871.

Sims, R.L. (1999). The development of six ethical business dilemmas. Leadership \& Organization Development Journal, 20, 189-97. 
Singhapakdi, A., Vitell, S., \& Rao, C.P. (1997). Professional values and perception underlying ethical judgements: a survey of marketing professionals in Thailand. Journal of Asia-Pacific Business, 2, 51-65.

Siu, N.Y.M. (2001). An empirical investigation of the ethical beliefs of consumers in China. BRC Papers on China.CP 200103. Department of Marketing, Hong Kong Baptist University.

Skoe, E.E., Cumberland, A., Eisenberg, N., Hansen, K., \& Perry, J. (2002). The influence of sex and gender-role identity on moral cognition and prosocial personality traits, Sex Roles, 46, 295-309.

Snider, J., Hill, R., \& Martin, D. (2003). Corporate social responsibility in the $21^{\text {st }}$ century: a view from the world's most successful firms. Journal of Business Ethics, 48, 175-187.

Srnka, K. J. (2004). Culture's role in marketers' ethical decision making: an integrated theoretical framework. Academy of Marketing Science Review, 1, 1-32.

Strong, C. (1996). Features contributing to the growth of ethical consumerism-a preliminary investigation. Marketing Intelligence \& Planning, 14, 5-13.

Supriti, M., \& Damodar, S. (2010). Does corporate social responsibility influence firm performance of Indian companies?. Journal of Business Ethics, 95, 571-601, September.

Thoma, S.J. (1986). Estimating gender differences in the comprehension and preference of moral issues. Developmental Review, 6, 165-180.

Tsalikis, J., \& Ortiz-Buonafina, M. (1990). Ethical belief differences of males and females. Journal of Business Ethics, 9, 509-517

Tsoi, J. (2010). Stakeholders perceptions and future scenarios to improve corporate social responsibility in Hong Kong and Mainland China. Journal of Business Ethics, 91, 391-404.

Varadarajan, P.R., \& Menon, A. (1988). Cause-related marketing: a co alignment of marketing strategy and corporate philanthropy. Journal of Marketing, 52, 58-74.

Visser, W. (2007). Corporate social responsibility in developing countries. In The Oxford Handbook of Corporate Social Responsibility (ed. By A. Crane, A. Mc. Williams, D. Matten, J. Moon and D. Siegel). Oxford University Press, Oxford.

Vitell, S.J., Lumpkin, J.R., \& Rawwas, M.Y.A. (1991). Consumer ethics: an investigation of the ethical beliefs of elderly consumers. Journal of Business Ethics, 10, 365-375.

Vitell, S.J. (2003). Consumer ethics research: review, synthesis and suggestions for future. Journal of Business Ethics, 43, 33-47.

World Bank (2000). Higher education in developing countries: peril and promise. Retrieved from http://www.accesstosuccess-africa.eu/web/images/literature/peril_and_promise.pdf [accessed 11 September 2012]. 
World Bank. (2006). Gender equality and development—progress in Indonesia. Retrieved from

http://web.worldbank.org/WBSITE/EXTERNAL/COUNTRIES/EASTASIAPACIFICEXT/I

NDONESIAEXTN/0,,contentMDK:20864480 pagePK:141137 piPK:141127 theSitePK:22 6309,00.html.

Xu, S., \& Yang, R. (2010). Indigenous characteristics of Chinese corporate social responsibility conceptual paradigm. Journal of Business Ethics, 93, 321-333.

Yates, L. (2011). Critical consumption. European Societies, 13, 191-217. 


\section{APPENDIX}

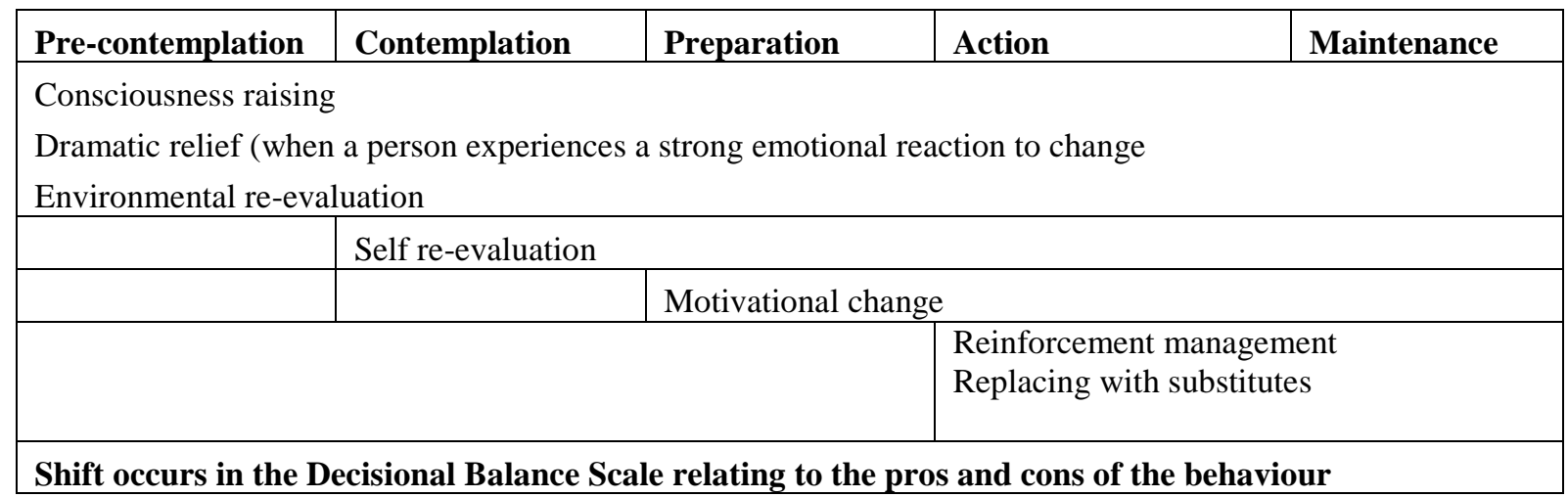

Source: Freestone andMcGoldrick (2008)

FIGURE 1. Adaptation of Change Processes in the SOC Model 


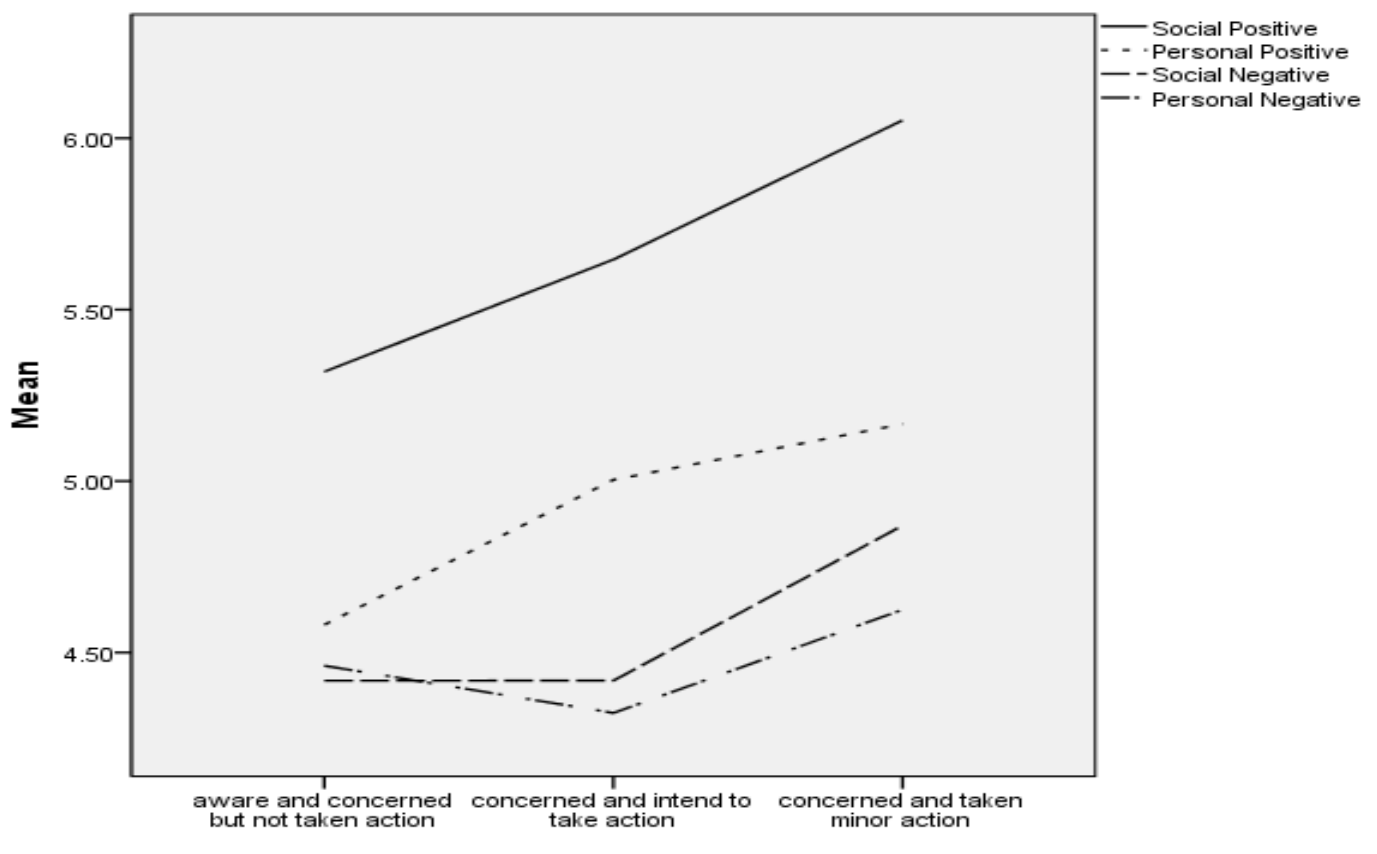

FIGURE 2. Decisional Balance Scales by Awareness, Concern and Action Stage [Women]

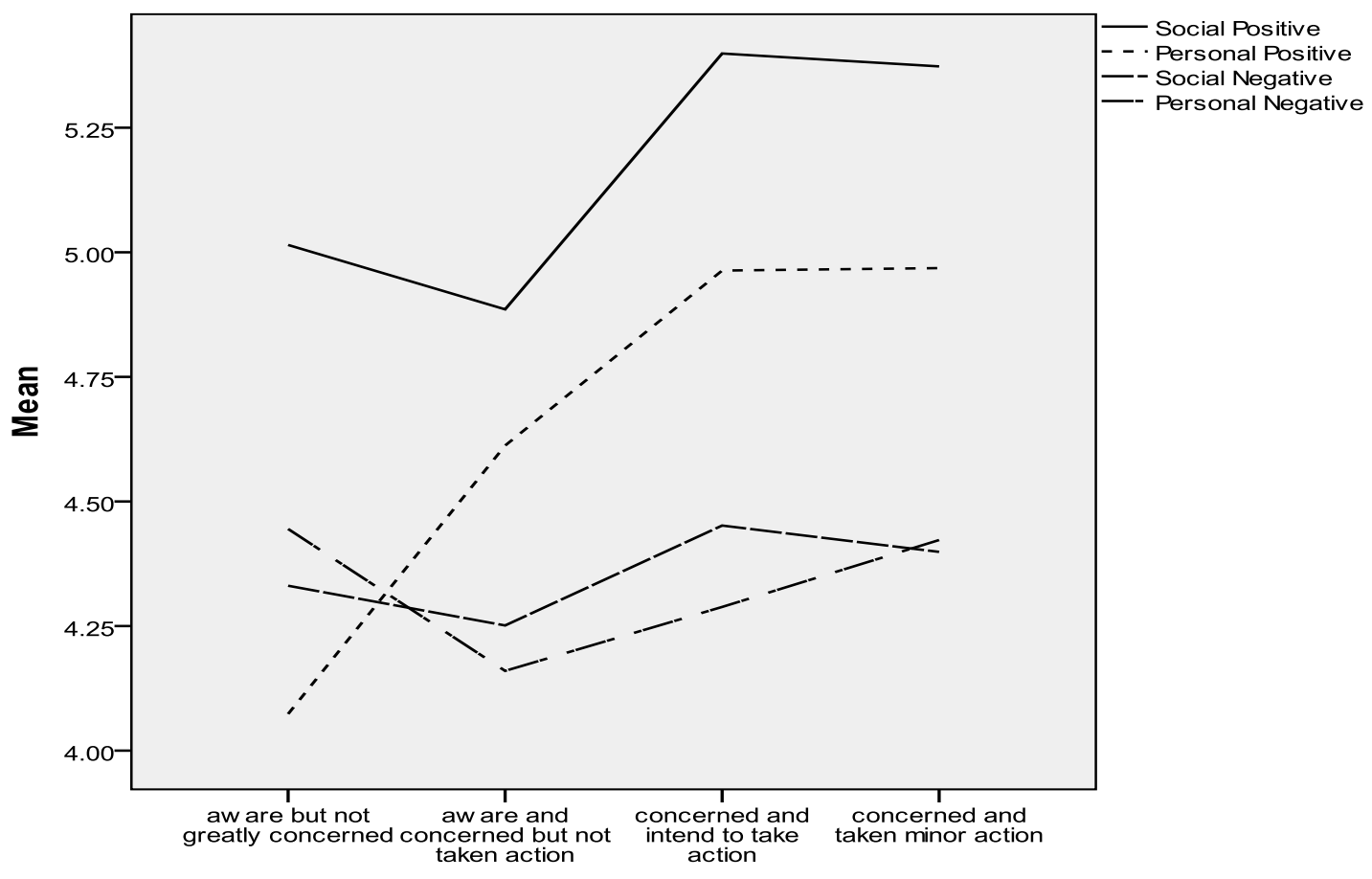

FIGURE 3. Decisional balance scales by awareness, concern and action stage [Men] 
TABLE 1. Summary of Empirical Studies of the Impact of CSR on Consumers in Developed Countries

\begin{tabular}{|c|c|c|c|}
\hline Author(s), year & Context & Main Findings & Journal \\
\hline Brown and Dacin, 1997 & USA & $\begin{array}{l}\text { Consumers' knowledge aboutCSR } \\
\text { may influence their beliefs and } \\
\text { attitude toward products launched } \\
\text { by a company. }\end{array}$ & Journal of Marketing \\
\hline Creyer and Ross, 1997 & USA & $\begin{array}{l}\text { Consumers reward a company's } \\
\text { ethical behaviour by a willingness } \\
\text { to pay higher price for that firm's } \\
\text { product. }\end{array}$ & $\begin{array}{l}\text { Journal of Consumer } \\
\text { Marketing }\end{array}$ \\
\hline Maignan, 2001 & $\begin{array}{ll}\text { USA, } & \text { French, } \\
\text { German } & \end{array}$ & $\begin{array}{l}\text { Each country has different } \\
\text { evaluations of the economic, } \\
\text { legal, ethical and philanthropic } \\
\text { responsibilities of the firm. }\end{array}$ & $\begin{array}{l}\text { Journal of Business } \\
\text { Ethics }\end{array}$ \\
\hline $\begin{array}{l}\text { Sen and Bhattacharya, } \\
2001\end{array}$ & USA & $\begin{array}{l}\text { Consumers' perceptions of CSR } \\
\text { may affect their purchasing } \\
\text { behaviour and, in certain } \\
\text { conditions, decrease consumers' } \\
\text { intentions to buy a company's } \\
\text { product. }\end{array}$ & $\begin{array}{l}\text { Journal of Marketing } \\
\text { Research }\end{array}$ \\
\hline Auger et al., 2003 & $\begin{array}{l}\text { Australia, Hong } \\
\text { Kong }\end{array}$ & $\begin{array}{l}\text { Most consumers are ignorant of } \\
\text { the ethical features that comprise } \\
\text { the products they consider and } \\
\text { purchase. }\end{array}$ & $\begin{array}{l}\text { Journal of Business } \\
\text { Ethics }\end{array}$ \\
\hline $\begin{array}{l}\text { Bhattacharya and Sen, } \\
2004\end{array}$ & USA & $\begin{array}{l}\text { Consumers' lack of awareness } \\
\text { about CSR initiatives is a major } \\
\text { barrier to their ability to respond } \\
\text { to initiatives. }\end{array}$ & $\begin{array}{l}\text { California Management } \\
\text { Review }\end{array}$ \\
\hline Becker-Olsen et al., 2006 & USA & $\begin{array}{llr}\begin{array}{l}\text { Low-fit } \\
\text { affect }\end{array} & \text { initiatives } & \text { negatively } \\
\text { attitudes } & \text { and intentions } & \text { beliefs, } \\
\text { CSR; } & \text { proactive } & \text { initiatives } \\
\text { improve } & \text { consumers' } & \text { beliefs, } \\
\text { attitudes and intentions. } & \end{array}$ & $\begin{array}{l}\text { Journal of Business } \\
\text { Research }\end{array}$ \\
\hline Mohr and Webb, 2005 & USA & $\begin{array}{l}\text { CSR has a positive impact on } \\
\text { evaluations of the company and } \\
\text { purchase intentions; the } \\
\text { environmental domain affects } \\
\text { purchase intentions most. }\end{array}$ & $\begin{array}{l}\text { Journal of Consumer } \\
\text { Affairs }\end{array}$ \\
\hline Honkanen et al., 2006 & Norway & $\begin{array}{l}\text { The more consumers are } \\
\text { concerned about ethical issues, the } \\
\text { more positive their attitudes and } \\
\text { the more likely they are to } \\
\text { consume products. }\end{array}$ & $\begin{array}{l}\text { Journal of Consumer } \\
\text { Behaviour }\end{array}$ \\
\hline $\begin{array}{ll}\text { Freestone } & \text { and } \\
\text { McGoldrick, } 2008 & \end{array}$ & United Kingdom & $\begin{array}{l}\text { Motivational attitudes are a } \\
\text { function of respondents' stage of } \\
\text { ethical awareness, concern and } \\
\text { action. }\end{array}$ & $\begin{array}{l}\text { Journal of Business } \\
\text { Ethics }\end{array}$ \\
\hline $\begin{array}{l}\text { McGoldrick and Collins, } \\
2007\end{array}$ & United Kingdom & $\begin{array}{l}\text { Consumers are willing to pay } \\
\text { premium prices if they are } \\
\text { convinced of a product's ethical } \\
\text { credentials }\end{array}$ & $\begin{array}{l}\text { Review of Retail, } \\
\begin{array}{l}\text { Distribution and } \\
\text { Consumer Research }\end{array}\end{array}$ \\
\hline
\end{tabular}


TABLE 2. Summary of Empirical Studies on the Impact of CSR on Consumers in Developing Countries

\begin{tabular}{|c|c|c|c|}
\hline Author(s), year & Context & Main Findings & Journal \\
\hline Al-Khatib et al., 2003 & $\begin{array}{lr}\text { Saudi } & \text { Arabia, } \\
\text { Oman } & \text { and } \\
\text { Kuwait } & \end{array}$ & $\begin{array}{l}\text { Consumers in developing } \\
\text { countries can be divided into three } \\
\text { segments: principled purchasers } \\
\text { (i.e. more trusting of others); } \\
\text { suspicious shoppers (i.e. proceed } \\
\text { with caution but emphasise ethical } \\
\text { behaviour) and corrupt consumers } \\
\text { (i.e. not ethically oriented and } \\
\text { take advantage of opportunity). }\end{array}$ & $\begin{array}{l}\text { International Marketing } \\
\text { Review }\end{array}$ \\
\hline Jamali, 2007 & Lebanon & $\begin{array}{l}\text { CSR is perceived as merely } \\
\text { voluntary } \\
\text { contributions. }\end{array}$ & Business and Society \\
\hline $\begin{array}{l}\text { Ramasamy and Yeung } \\
2009\end{array}$ & China & $\begin{array}{l}\text { Economic responsibilities are the } \\
\text { most important; philanthropic is } \\
\text { the least important. }\end{array}$ & $\begin{array}{l}\text { Journal of Business } \\
\text { Ethics }\end{array}$ \\
\hline Auger et al., 2010 & Turkey and India & $\begin{array}{l}\text { Despite getting information about } \\
\text { social attributes, consumers still } \\
\text { put more emphasis on brand than } \\
\text { consumers from developed } \\
\text { countries. }\end{array}$ & $\begin{array}{l}\text { Journal of Business } \\
\text { Ethics }\end{array}$ \\
\hline Siu, 2001. & China & $\begin{array}{l}\text { People with more education show } \\
\text { more ethical concern than those in } \\
\text { lower social classes. }\end{array}$ & BRC Paper on China \\
\hline Xu and Yang, 2010 & China & $\begin{array}{l}\text { CSR is closely related to social } \\
\text { and cultural background, and } \\
\text { some dimensions are very } \\
\text { different from their Western } \\
\text { counterparts. }\end{array}$ & $\begin{array}{l}\text { Journal of Business } \\
\text { Ethics }\end{array}$ \\
\hline
\end{tabular}

TABLE 3. Scale Items and Exploratory Factor Analysis of Corporate Social Responsibilities

\begin{tabular}{|c|c|c|c|c|}
\hline \multirow{2}{*}{ I believe that business must } & \multicolumn{4}{|c|}{ Component } \\
\hline & PHI & ECO & LEG & ETH \\
\hline Participate in the management of public affairs. & .830 & & & \\
\hline Help solve social problems. & .785 & & & \\
\hline $\begin{array}{l}\text { Play a role in our society that goes beyond the } \\
\text { mere generation of profits. }\end{array}$ & .708 & & & \\
\hline Maximize profits. & & .810 & & \\
\hline Always improve economic performance. & & .771 & & \\
\hline Plan for their long-term success. & & .720 & & \\
\hline $\begin{array}{l}\text { Refrain from bending the law even if this helps } \\
\text { improve performance. }\end{array}$ & & & .878 & \\
\hline $\begin{array}{l}\text { Refrain from putting aside their contractual } \\
\text { obligations. }\end{array}$ & & & .866 & \\
\hline $\begin{array}{l}\text { Ensure that the respect of ethical principles has } \\
\text { priority over that economic performance. }\end{array}$ & & & & .865 \\
\hline $\begin{array}{l}\text { Permit ethical concerns to negatively affect } \\
\text { economic performance. }\end{array}$ & & & & .835 \\
\hline Cronbach’salpha & 0.70 & 0.64 & 0.73 & 0.66 \\
\hline Total variance explained & $63 \%$ & & & \\
\hline
\end{tabular}

Notes: $\quad$ PHI= philanthropic responsibilities; $\quad$ ECO=economic responsibilities; LEG=legal responsibilities; ETH=ethical responsibilities. 
TABLE 4. Two-factor Solution for DBS

Principal component loadings: two-components solution (orthogonal)

\begin{tabular}{|c|c|c|}
\hline \multirow{2}{*}{$\begin{array}{l}\text { Decisional balance items } \\
\text { Positive Motivations (Pros) Cronbach's Alpha: } 0.809\end{array}$} & \multicolumn{2}{|c|}{ Component } \\
\hline & 1 & 2 \\
\hline $\begin{array}{l}\text { It would be better for everyone in the long run if people favoured } \\
\text { products that address this issue. }\end{array}$ & & .703 \\
\hline $\begin{array}{l}\text { It would help if people bought from firms that address this issue } \\
\text { this issue. }\end{array}$ & & .701 \\
\hline \multirow{2}{*}{ I feel more responsible if I favour products that address this issue. } & & 685 \\
\hline & & 657 \\
\hline \multicolumn{3}{|l|}{$\begin{array}{l}\text { People could make fairer choices if they were aware of which } \\
\text { companies had high ethical principles regarding this issue. }\end{array}$} \\
\hline This is an issue that I like to be associated with. & & .640 \\
\hline $\begin{array}{l}\text { I feel better about myself if I take some form of action against } \\
\text { firms that violate this issue. }\end{array}$ & & .614 \\
\hline $\begin{array}{l}\text { People who matter to me would respect me for being concerned } \\
\text { about this issue. }\end{array}$ & & .588 \\
\hline \multicolumn{3}{|l|}{ Negative Motivations (Cons) Cronbach's Alpha: 0.803} \\
\hline $\begin{array}{l}\text { It would make shopping less convenient if I had to choose only } \\
\text { from products that support this issue. }\end{array}$ & .735 & \\
\hline $\begin{array}{l}\text { It would take the pleasure out of shopping if I had to choose only } \\
\text { from products that support this issue. }\end{array}$ & .687 & \\
\hline $\begin{array}{l}\text { Having to take account of this issue would make shopping less } \\
\text { convenient for people. }\end{array}$ & 659 & \\
\hline $\begin{array}{l}\text { My friends would think it was uncool to be concerned with this } \\
\text { issue. }\end{array}$ & .585 & \\
\hline It costs more to take account of this issue when shopping. & .585 & \\
\hline $\begin{array}{l}\text { It would be too much hassle to buy only from businesses that do } \\
\text { not violate this issue. }\end{array}$ & .569 & \\
\hline $\begin{array}{l}\text { People would be annoyed if they were pressured into being } \\
\text { concerned with }\end{array}$ & .528 & \\
\hline $\begin{array}{l}\text { People might think it was a waste of time to try to influence big } \\
\text { business over }\end{array}$ & .519 & \\
\hline $\begin{array}{l}\text { People's choices would be unreasonably restricted by the removal } \\
\text { of products that disregard this issue. }\end{array}$ & .506 & \\
\hline
\end{tabular}


TABLE 5. Four-factor Solution for DBS

\begin{tabular}{|c|c|c|c|c|}
\hline & $\begin{array}{l}\text { Personal } \\
\text { Negative }\end{array}$ & $\begin{array}{l}\text { Social } \\
\text { Positive }\end{array}$ & $\begin{array}{l}\text { Personal } \\
\text { Positive }\end{array}$ & $\begin{array}{l}\text { Social } \\
\text { Negative }\end{array}$ \\
\hline $\begin{array}{l}\text { It would help if people bought from } \\
\text { firms that address this issue. }\end{array}$ & & 0.81 & & \\
\hline $\begin{array}{l}\text { I feel more responsible if I favour } \\
\text { products that address this issue. }\end{array}$ & & 0.81 & & \\
\hline $\begin{array}{l}\text { People could make fairer choices if } \\
\text { they were aware of which companies } \\
\text { had high ethical principles regarding } \\
\text { this }\end{array}$ & & 0.55 & & \\
\hline $\begin{array}{l}\text { This is an issue that I like to be } \\
\text { associated with. }\end{array}$ & & & 0.52 & \\
\hline $\begin{array}{l}\text { People who matter to me would } \\
\text { respect me for being concerned about } \\
\text { this issue. }\end{array}$ & & & 0.78 & \\
\hline $\begin{array}{l}\text { My friends are concerned about this } \\
\text { issue. }\end{array}$ & & & 0.79 & \\
\hline $\begin{array}{l}\text { Having to take account of this issue } \\
\text { would make shopping less convenient } \\
\text { for people. }\end{array}$ & 0.66 & & & \\
\hline $\begin{array}{l}\text { It would make shopping less } \\
\text { convenient if I had to choose only } \\
\text { from products that support this issue. }\end{array}$ & 0.85 & & & \\
\hline $\begin{array}{l}\text { It would take the pleasure out of } \\
\text { shopping if I had to choose only from } \\
\text { products that support this issue. }\end{array}$ & 0.79 & & & \\
\hline $\begin{array}{l}\text { It would be too much hassle to buy } \\
\text { only from businesses that do not } \\
\text { violate this issue. }\end{array}$ & 0.62 & & & \\
\hline $\begin{array}{l}\text { People are too busy today to be } \\
\text { concerned with this issue. }\end{array}$ & & & & 0.83 \\
\hline $\begin{array}{l}\text { People might think it was a waste of } \\
\text { time to try to influence big business } \\
\text { over this issue. }\end{array}$ & & & & 0.72 \\
\hline Cronbach's alpha & 0.74 & 0.67 & 0.63 & 0.51 \\
\hline
\end{tabular}

Notes: Total variance explained $=63 \% \mathrm{KMO}=.728$; Bartlett's test $\chi^{2}=1037.9, \mathrm{df}=66, p=0.000$.

TABLE 6. Importance Attributed to Corporate Social Responsibility (women)

\begin{tabular}{|l|l|l|l|}
\hline & Mean & SD & Post Hoc (sig) \\
\hline (1) PHI & 4.20 & 0.577 & $(3),(4)$ \\
\hline (2) ECO & 4.16 & 0.560 & $(3),(4)$ \\
\hline (3) ETH & 3.46 & 0.714 & $(1),(2),(4)$ \\
\hline (4) LEG & 1.90 & 0.905 & $(1),(2),(3)$ \\
\hline
\end{tabular}

TABLE 7. Importance Attributed to Corporate Social Responsibility (men)

\begin{tabular}{|l|l|l|l|}
\hline & Mean & SD & Post Hoc (sig) \\
\hline (1) PHI & 4.18 & 0.532 & $(3),(4)$ \\
\hline (2) ECO & 4.32 & 0.559 & $(3),(4)$ \\
\hline (3) ETH & 3.51 & 0.847 & $(1),(2),(4)$ \\
\hline (4) LEG & 1.92 & 0.775 & $(1),(2),(3)$ \\
\hline
\end{tabular}


TABLE 8. Comparison of Importance Attributed to Corporate Social Responsibility

\begin{tabular}{|c|c|c|c|c|c|c|c|c|c|}
\hline & \multicolumn{4}{|c|}{ Mean (Female) } & \multicolumn{4}{|c|}{ Mean (Male) } & \multirow[t]{2}{*}{ Sig } \\
\hline & & & S.D. & $N$ & & & S.D. & $N$ & \\
\hline PHI & 4.20 & (1) & .57716 & 357 & 4.18 & (2) & 0.53 & 82 & 0.78 \\
\hline ECO & 4.16 & (2) & .56063 & 357 & 4.33 & (1) & 0.56 & 82 & 0.01 \\
\hline ETH & 3.46 & (3) & .71450 & 357 & 3.51 & (3) & 0.78 & 82 & 0.86 \\
\hline LEG & 1.90 & (4) & .90577 & 357 & 1.92 & (4) & 0.85 & 82 & 0.62 \\
\hline
\end{tabular}

Notes: $1=$ strongly disagree; $5=$ Strongly agree.

TABLE 9. Attributes Considered at Purchase

\begin{tabular}{|l|l|l|l|l|}
\hline Attribute & Mean (Female) & Mean (Male) & F & Sig \\
\hline Quality & 4.41 & 4.42 & 0.45 & 0.83 \\
\hline Price & 3.91 & 4.03 & 1.48 & 0.23 \\
\hline Brand & 3.73 & 3.72 & 0.03 & 0.87 \\
\hline Ingredients & 3.78 & 3.56 & 3.34 & 0.07 \\
\hline Packaging & 3.13 & 3.16 & 0.56 & 0.81 \\
\hline Convenience & 3.09 & 2.97 & 1.35 & 0.25 \\
\hline What charity it supports & 2.85 & 2.63 & 3.96 & $\mathbf{0 . 0 5}$ \\
\hline Whether it supports a charity & 2.87 & 2.55 & 9.55 & $\mathbf{0 . 0 0}$ \\
\hline
\end{tabular}

Notes: $1=$ not considered at all; $5=$ considered to a great extent.

TABLE 10. Difference in Awareness and Concern between Genders

\begin{tabular}{|l|l|l|l|l|l|l|l|l|l|l|l|l|l|}
\hline & \multicolumn{9}{|l|}{ Female (\%) } & \multicolumn{2}{l|}{ Male (\%) } & $\begin{array}{l}\text { Chi- } \\
\text { square }\end{array}$ \\
\hline & ANC & ACNA & CIA & CMinA & CMajA & Rank & ANC & ACNA & CIA & CminA & CMajA & Rank & \\
\hline Health & 2 & 32 & 40 & 35 & 3 & $(1)$ & 5 & 38 & 60 & 24 & 3 & $(1)$ & 7.67 \\
\hline Climate & 2 & 35 & 25 & 33 & 4 & $(3)$ & 5 & 36 & 36 & 17 & 5 & $(2)$ & $17.05^{*}$ \\
\hline Environ & 2 & 34 & 32 & 27 & 4 & $(2)$ & 5 & 43 & 29 & 17 & 5 & $(3)$ & 8.92 \\
\hline Animal & 6 & 42 & 29 & 17 & 4 & $(4)$ & 7 & 40 & 32 & 14 & 3 & $(4)$ & 4.87 \\
\hline Local problem & 14 & 53 & 20 & 10 & 2 & $(5)$ & 11 & 49 & 27 & 11 & 1 & $(5)$ & 6.78 \\
\hline $3^{\text {rd }}$ world & 30 & 48 & 11 & 4 & 1 & $(6)$ & 28 & 47 & 13 & 3 & 1 & $(6)$ & 1.75 \\
\hline
\end{tabular}

$* p<0.01$.

Notes: ANC = aware but not greatly concerned; $\mathrm{ACNA}=$ aware, concerned but not taken action; CIA = concerned and intend to take action; CMin A = concerned and taken minor action; and CMajA = concerned and taken major action. Ranks based on CIA + CMinA + CMajA percentages. 
TABLE 11. Analysis of Variance and Post-hoc Test for DBS by ACA Stage [women]

\begin{tabular}{|c|c|c|c|c|c|}
\hline \multirow{4}{*}{$\begin{array}{l}\text { DBS Scale } \\
\text { Social Positives }\end{array}$} & Awareness, Concern, Action Stage & $\mathbf{N}$ & Mean & SD & Post Hoc* \\
\hline & (a) Aware and concerned but not taken action & 70 & 5.32 & 0.93 & (4) \\
\hline & (b) Concerned and intent to take action & 61 & 5.65 & 1.04 & - \\
\hline & (c) Concerned and taken minor action & 27 & 6.05 & 0.68 & (2) \\
\hline \multirow{2}{*}{\multicolumn{2}{|c|}{ ANOVA: Social Positives }} & & df & $\mathrm{F}$ & $p$ \\
\hline & & & 2.00 & 6.21 & 0.00 \\
\hline \multirow{4}{*}{$\begin{array}{l}\text { Personal } \\
\text { Positives }\end{array}$} & & & & & \\
\hline & (a) Aware and concerned but not taken action & 70 & 4.58 & 1.06 & (4) \\
\hline & (b) Concerned and intent to take action & 61 & 5.00 & 1.07 & - \\
\hline & (c) Concerned and taken minor action & 27 & 5.17 & 1.03 & (2) \\
\hline \multirow{2}{*}{\multicolumn{2}{|c|}{ ANOVA: Personal Positives }} & & df & $\mathrm{F}$ & $p$ \\
\hline & & & 2.00 & 4.09 & 0.02 \\
\hline \multirow[t]{3}{*}{ Social Negatives } & (a) Aware and concerned but not taken action & 70 & 4.42 & 1.46 & - \\
\hline & (b) Concerned and intent to take action & 61 & 4.42 & 1.57 & - \\
\hline & (c) Concerned and taken minor action & 27 & 4.87 & 1.30 & - \\
\hline \multirow{2}{*}{\multicolumn{2}{|c|}{ ANOVA: Social Negatives }} & & df & $\mathrm{F}$ & $p$ \\
\hline & & & 2.00 & 1.04 & 0.35 \\
\hline \multirow{4}{*}{$\begin{array}{l}\text { Personal } \\
\text { Negatives }\end{array}$} & & & & & \\
\hline & (a) Aware and concerned but not taken action & 70 & 4.46 & 1.12 & - \\
\hline & (b) Concerned and intent to take action & 61 & 4.32 & 1.20 & - \\
\hline & (c) Concerned and taken minor action & 27 & 4.63 & 1.08 & - \\
\hline \multirow{2}{*}{\multicolumn{2}{|c|}{ ANOVA: Personal Negatives }} & & df & $\mathrm{F}$ & $p$ \\
\hline & & & 2.00 & 0.68 & 0.51 \\
\hline
\end{tabular}


TABLE 12. Analysis of Variance and Post-hoc Test for DBS by ACA Stage [men]

\begin{tabular}{|c|c|c|c|c|c|}
\hline DBS Scale & Awareness, Concern, Action Stage & $\mathbf{N}$ & Mean & SD & Post Hoc* \\
\hline \multirow[t]{4}{*}{ Social Positives } & (a) Aware but not greatly concerned & 17 & 5.01 & 0.86 & - \\
\hline & (b) Aware and concerned but not taken action & 107 & 4.89 & 1.02 & (4) \\
\hline & (c) Concerned and intent to take action & 75 & 5.40 & 0.89 & (3) \\
\hline & (d) Concerned and taken minor action & 21 & 5.37 & 0.90 & - \\
\hline \multirow{2}{*}{\multicolumn{3}{|c|}{ ANOVA: Personal Positives }} & df & $\mathrm{F}$ & $p$ \\
\hline & & & 3.00 & 4.86 & 0.00 \\
\hline \multicolumn{6}{|l|}{ Personal } \\
\hline \multirow[t]{4}{*}{ Positives } & (a) Aware but not greatly concerned & 17 & 4.07 & 0.82 & (4) \\
\hline & (b) Aware and concerned but not taken action & 107 & 4.61 & 1.15 & - \\
\hline & (c) Concerned and intent to take action & 75 & 4.96 & 1.03 & (2) \\
\hline & (d) Concerned and taken minor action & 21 & 4.97 & 1.07 & - \\
\hline \multirow{2}{*}{\multicolumn{2}{|c|}{ ANOVA: Social Positives }} & & df & $\mathrm{F}$ & $p$ \\
\hline & & & 3.00 & 4.00 & 0.01 \\
\hline \multirow[t]{4}{*}{ Social Negatives } & (a) Aware but not greatly concerned & 17 & 4.33 & 1.53 & - \\
\hline & (b) Aware and concerned but not taken action & 107 & 4.25 & 1.26 & - \\
\hline & (c) Concerned and intent to take action & 75 & 4.45 & 1.32 & - \\
\hline & (d) Concerned and taken minor action & 21 & 4.40 & 1.41 & - \\
\hline \multirow{2}{*}{\multicolumn{2}{|c|}{ ANOVA: Personal Negatives }} & & df & $\mathrm{F}$ & $p$ \\
\hline & & & 3.00 & 0.36 & 0.78 \\
\hline \multicolumn{6}{|l|}{ Personal } \\
\hline \multirow[t]{4}{*}{ Negatives } & (a) Aware but not greatly concerned & 17 & 4.44 & 1.19 & - \\
\hline & (b) Aware and concerned but not taken action & 107 & 4.16 & 0.93 & - \\
\hline & (c) Concerned and intent to take action & 75 & 4.29 & 1.13 & - \\
\hline & (d) Concerned and taken minor action & 21 & 4.42 & 1.06 & - \\
\hline \multirow{2}{*}{\multicolumn{2}{|c|}{ ANOVA: Social Negatives }} & & df & $\mathrm{F}$ & $p$ \\
\hline & & & 3.00 & 0.699 & 0.553 \\
\hline
\end{tabular}


TABLE 13. Summary of Findings

\begin{tabular}{|l|l|}
\hline Hypothesis & Result \\
\hline $\begin{array}{l}\boldsymbol{H}_{1}: \text { 'Consumer in Indonesia will NOT be able to distinguish the different } \\
\text { types of CSR. }\end{array}$ & Rejected \\
\hline $\begin{array}{l}\mathbf{H}_{2}: \text { The DBS and SOC models used to describe ethical behaviour hold in } \\
\text { the context of Indonesia }\end{array}$ & Supported \\
\hline $\begin{array}{l}\boldsymbol{H}_{3}: \text { Men and women in Indonesia are NOT ethically equivalent, that is, } \\
\text { they DO NOT place the same level of importance on CSR responsibilities. }\end{array}$ & Rejected \\
\hline $\begin{array}{l}\boldsymbol{H}_{4}: \text { In purchase decision contexts, there are NO significant differences in } \\
\text { the social attributes considered by men and women. }\end{array}$ & Rejected \\
\hline $\begin{array}{l}\boldsymbol{H}_{5 a}: \text { The social positive and personal positive scales for women in } \\
\text { developing countries are higher in later stages of awareness, concern and } \\
\text { action, compared with early stages. }\end{array}$ & Supported \\
\hline $\begin{array}{l}\boldsymbol{H}_{5 b}: \text { The social negative and personal negative scales for women in } \\
\text { developing countries are lower in later stages of awareness, concern and } \\
\text { action, compared with early stages. }\end{array}$ & Rejected \\
\hline $\begin{array}{l}\boldsymbol{H}_{6 a}: \text { The social positive and personal positive scales for men in developing } \\
\text { countries are higher in the later stages of awareness, concern and action, } \\
\text { compared with early stages. }\end{array}$ & Rejected \\
\hline $\begin{array}{l}\boldsymbol{H}_{6 b}: \text { The social negative and personal negative scale for men in developing } \\
\text { countries are lower in the later stages of awareness, concern and action, } \\
\text { compared with early stages. }\end{array}$ & Rejected \\
\hline
\end{tabular}

